\title{
THE EXPERIMENTAL MONITORING OF WATER REGIME IN THE REKA RIVER
}

\section{EKSPERIMENTALNA OPAZOVANJA VODNEGA REŽIMA NA REKI REKI}

\author{
M. BRILLY ${ }^{1} \&$ M. MIKOŠ ${ }^{1} \&$ G. PETKOVŠEK ${ }^{1} \&$ M. ŠRAJ ${ }^{1} \&$ \\ J. KOGOVŠEK ${ }^{2} \&$ D. DROBNE ${ }^{3} \&$ L. ŠTRAVS ${ }^{1}$
}

${ }^{1}$ University of Ljubljana, Faculty of Civil Engineering and Geodesy, Hajdrihova 28, SI-1000 LJUBLJANA, SLOVENIA, mbrilly@fgg.uni-lj.si

${ }^{2}$ Karst Research Institute ZRC SAZU, Titov trg 2, SI-6230 POSTOJNA, SLOVENIA

${ }^{3}$ University of Ljubljana, Faculty of Biotehnics, Department of Biology, Večna pot 111, SI-1000 LJUBLJANA, SLOVENIA 


\section{Brilly \& M. Mikoš \& G. Petkovšek \& M. Šraj \& J. Kogovšek \& D. Drobne \& L. Štravs: Eksperimentalna opazovanja vodnega režima na reki Reki}

Reka Reka, s prispevno površino 422 km², ponika v Škocjanskih jamah, ki jih je UNESCO leta 1986 proglasil za svetovno dediščino. V sedemdesetih letih je bila Reka ena od najbolj onesnaženih rek v Sloveniji. V času visokih vod leta 1999 in 2000 smo izvedli meritve hitrosti, kalnosti, vrste fizikalnih in kemičnih parametrov ter teste strupenosti. Glavni cilji teh pionirskih meritev so bili preveriti mersko opremo v terenskih pogojih visokih voda, zbrati čimveč podatkov ter primerjati uporabnost opreme.

Ključne besede: meritve, oprema, hitrost, fizikalni parametri, kemijski parametri, toksičnost, reka Reka.

\section{Abstract}

UDC: 556.3.001.4

M. Brilly \& M. Mikoš \& G. Petkovšek \& M. Šraj \& J. Kogovšek \& D. Drobne \& L. Štravs: The experimental monitoring of the water regime in the Reka river

The river Reka, with 422 square kilometres of drainage area sinks into the Škocijan Cave system, which was proclaimed by UNESCO as a World Heritage Site in 1986. In the seventies, the Reka river was one of most polluted rivers in Slovenia. During floods in 1999 and 2000, experimental measurements of velocity, water level, suspended sediment transport, chemical parameters and toxicity tests were conducted. The main tasks in the first stage of the investigation: check the equipment in field conditions and test the toxicity of water in particular cross sections. In the paper, the measurements and some discussion of the results and applicability of equipment are presented.

Key words: measurement, equipment, physical parameters, chemical parameters, toxicity, Reka river. 


\section{INTRODUCTION}

The Reka river is the widest known sinking stream of a classical karst area, and it has been studied since antiquity. The river sinks into the Škocjan Cave system, which was proclaimed by UNESCO as a World Heritage Site in 1986. Then the groundwater stream flows to the karst springs of the Timav, and drains into the Adriatic Sea in the Trieste Bay, figure 1. Small part of the headwater and the spring are in the Croatia.

The Reka river Basin is situated on the Brkini syncline Eocene flysch rocks surrounded by a large karstic region, figure 2. The basin has an area of 442 sq. kilometres down to the sink in the Škocjan Caves. The stream network is well developed on the impermeable part of the basin. The stream density is about $1.696 \mathrm{~km} / \mathrm{km}^{2}$. The water from the northern karstic formation belongs also to the Danube river Basin, while the water from the southern part drains into the Adriatic Sea. There is an underground bifurcation from which the surface water flows to the Danube river and the underground water drainage in the Bistrica Spring, a tributary of the Reka river, (Rojšek, 1987).

There is the town Ilirska Bistrica and a lot of small villages, along the valley. The chemical and woodwork industry heavily polluted the river, which was one of most polluted stream in Slovenia. The main polluters were the fiberboard factory and the organic acids factory in Ilirska Bistrica. The $\mathrm{BOD}_{5}$ was between 100 and $200 \mathrm{mg} / \mathrm{l}$ during the mean flows in 1969 and 1979. Industrial water treatment was unsuccessful, and the Reka river valley was an unpleasant place

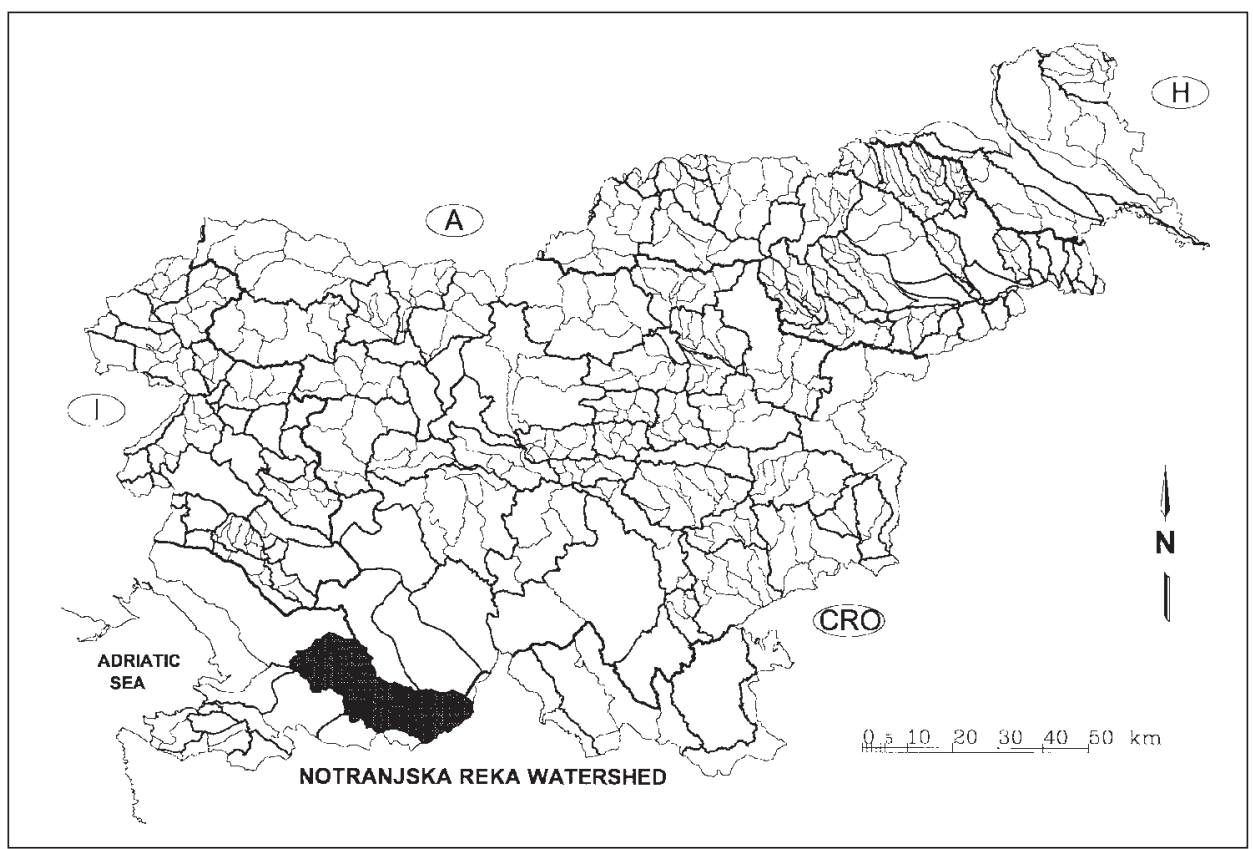

Fig. 1: Position of the Reka river Drainage Basin. 


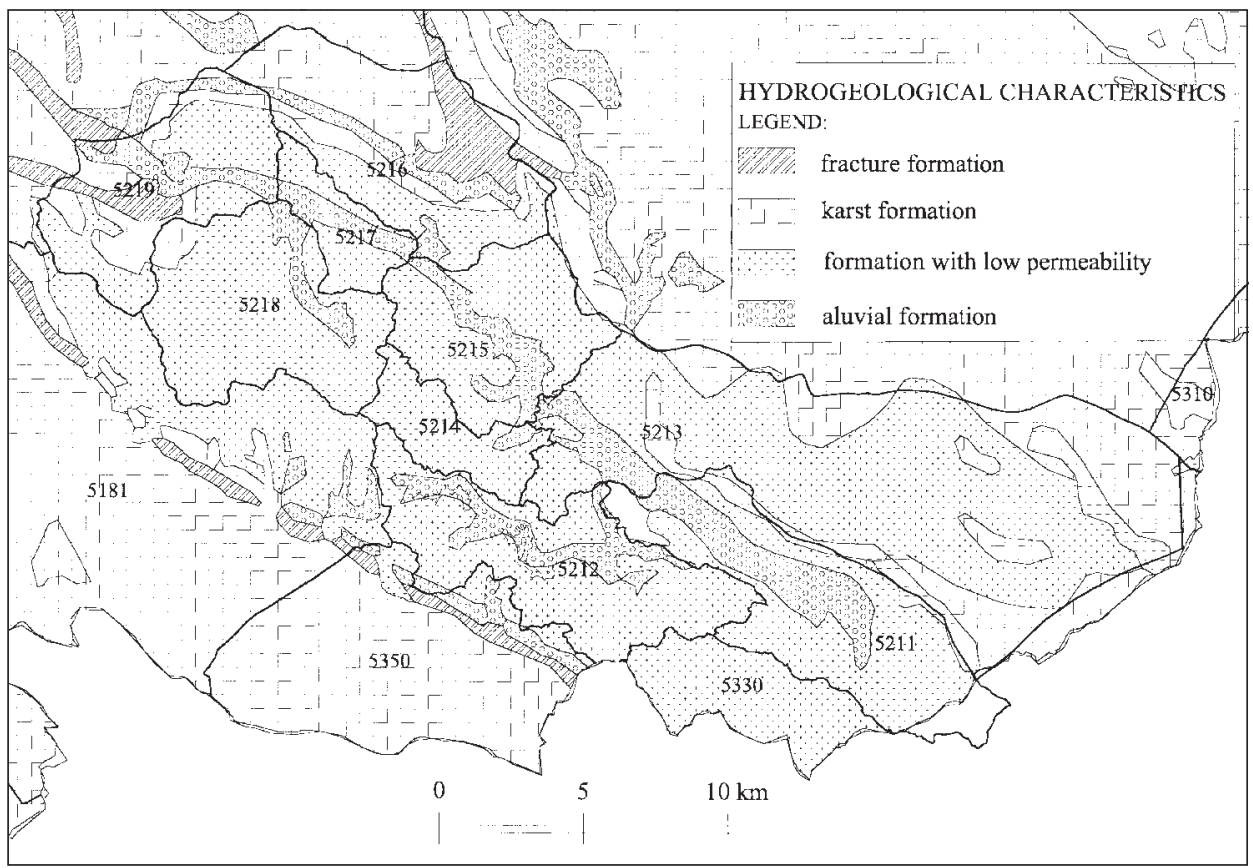

Fig. 2: Geology of the drainage area.

with a specific smell caused by the anaerobic processes in the river body, especially during the low flows, with discharge of only few hundred liters per second. Pollution prevention work started in the seventies. A wastewater treatment plant and two reservoirs for low flow recharge were constructed. In the nineties, the industrial production decreased and the pollution diminished.

There are three hydrological gauging stations in the Basin, figure 3. Two of them, Cerkvenikov mlin and Trnovo, are equipped with a recorder. The others are only staff gauges, and some of them have been abandoned. The Cerkvenikov mlin Hydrological Station was established in 1951. A large fluctuation in discharges can be observed there. The lowest discharges are in the summer time, when the natural discharge is below 200 litres per second. The basin and sub basin borders from the national hydrographic coding system are on the figures 1, 2 and 3, (Brilly et al., 2000).

The infiltration of water from the stream into the underground begins 600 meters downstream of the Cerkvenikov mlin. It depends on hydrological and morphological conditions, and changes in time almost after each flood wave. During the low flows, almost all the discharge disappears, and the Škocjan Caves are without surface water inflow. During 1982 and 1983, even the mean flows of the Reka river disappeared underground before the river reached the caves, which were without flowing water for 120 days. After that the riverbed clogged again.

The National Committee of the International Hydrological Programme of UNESCO decided, in 1998, to establish an experimental river basin on the Reka river, purchased the equipment, and started with experimental measurements in 1998-2000. 


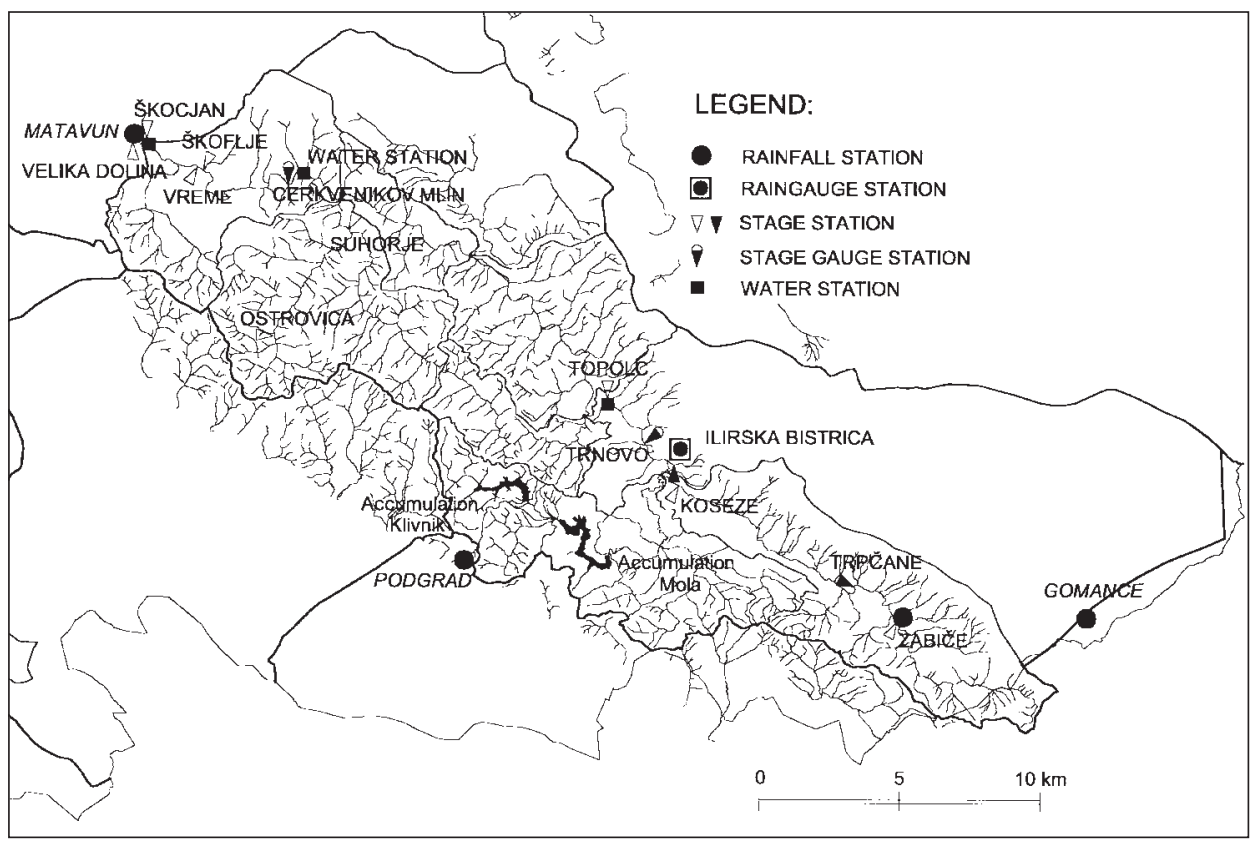

Fig. 3: The river network with measuring sites.

\section{RESULTS OF MEASUREMENTS AND DISCUSSION}

\section{Materials and Methods}

The equipment for the measurements at the experimental basin was purchased in 1998 and 1999. The items purchased were: a sediment sampler; a tahimeter; compact compound probes for the measurement of temperature, conductivity, oxygen and $\mathrm{pH}$; an ultrasonic Doppler instrument for the measurement of water velocity; a datalog current meter and a water level recorder.

The experimental measurements were done during flood discharges 21-24 May 1999, 16-21 November 1999, from 28 March to 5 April 2000, and from 11-17 April 2000. The measurement of velocity and discharge took place at the Cerkvenikov mlin state gauge station. Power supply was necessary for some of the other measurements, and these were moved $1.200 \mathrm{~m}$ upstream to the abandoned water supply station with an electrical power supply immediate to the riverbank, figure 3. Water samples for ecotoxical investigation were taken from a creek near an abandoned sewage disposal site and near the Cerkvenikov mlin gauge.

\section{Measurements of water velocity, water level and temperature}

We used three instruments to measure the velocity: Valeport Self Recording current meter; Starflow ultrasonic velocity meter and ISCO 6700 compatible Area-Velocity Module. The measurement during the first experiment provided us with good results. The equipment worked prop- 
erly and we obtained a good sample of data. The results of velocity measurement by ultrasonic instrument from the third experiment were also good, and the stage-velocity relationship fitted well with the first measurement, figure 4.

There was some discrepancy in the measurement of the water head with the Self Recording cur-

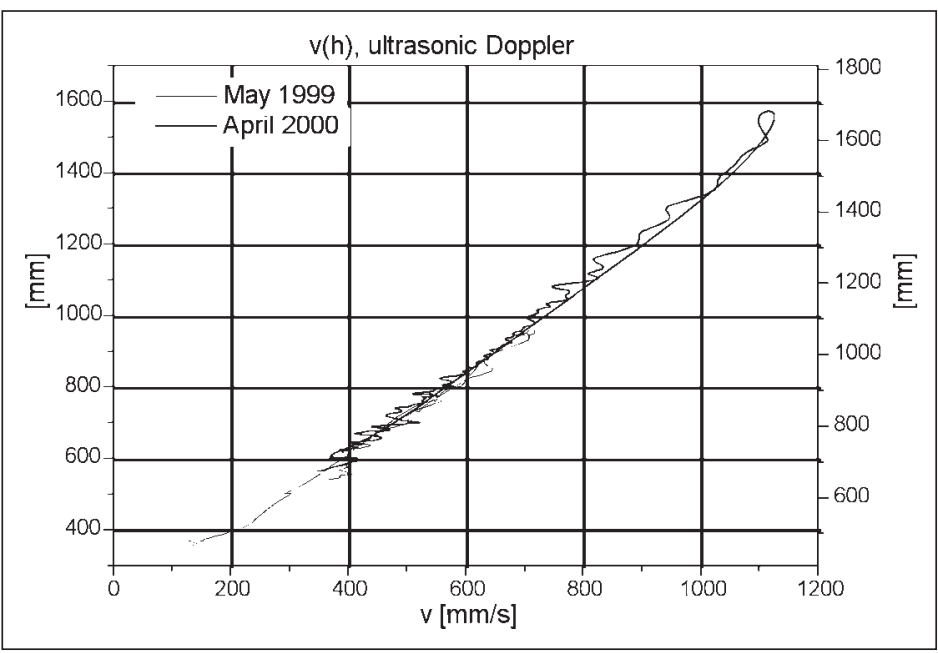

Fig. 4: Stage - velocity curve for two experiments. rent meter and other instruments The Self Recording current meter is also very vulnerable on floating debris, leaves, garbage etc., and could not stay in order without daily control.

The Starflow ultrasonic velocity meter has also probes for measurement of water level and temperature. The results of measurement of water level, temperature and velocity are on the figure 5. The measurement of temperature is interesting and very useful for further ecohydrological research.

\section{Measurement of suspended sediments}

For measurement of the suspended solids concentration we used the following instruments: Hach SS6 turbidimeter; Partech IR40 infrared sensor and ISCO 3700 sampler. The last two were installed on 29-30 March 2000 only, figure 5. The turbidimeter was not operating all the time, due to problems with pumping.

Therefore, we can assume that the differences in measured values were mostly due to the differences in measuring techniques. The direct method can be assumed to be a relatively accurate method, covering nearly all the sediment sizes $(\mathrm{d}>2 \mu \mathrm{m})$. Its disadvantage is that the samples are small, and, therefore, prone to turbulent oscillations. Other methods provide an averaging over the values continuously measured, but have other disadvantages. Infrared light absorption is rather sensitive to the size of particles and concentration. The turbidimeter is designed in such a way that only particles smaller than fine sand (i.e. washload) reach the point of measurement.

\section{Water quality measurement}

We measured temperature, $\mathrm{pH}$, conductivity (SEC) and dissolved oxygen (DO) of the Reka river at different hydrological conditions with a Sound YSI 600 compatible to the portable ISCO 6700 auto-sampler. Before the installation of the Sound in the field, for in-situ measurements, we performed a calibration of conductivity, $\mathrm{pH}$ (two-point calibration) and dissolved oxygen. Occasionally, we checked the Sound operation in the field with portable WTW instruments: tempera- 


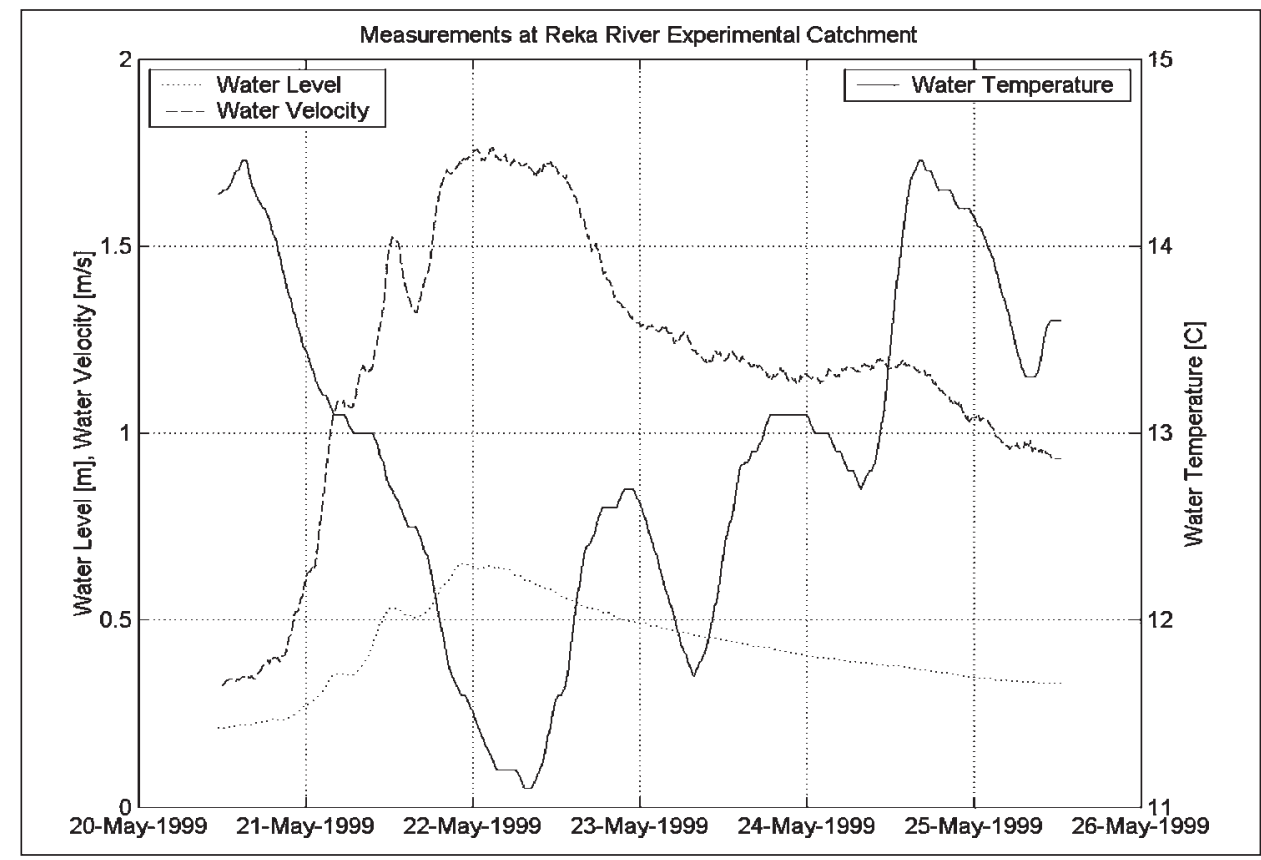

Fig. 5: Measurement of level, velocity and temperature of water.

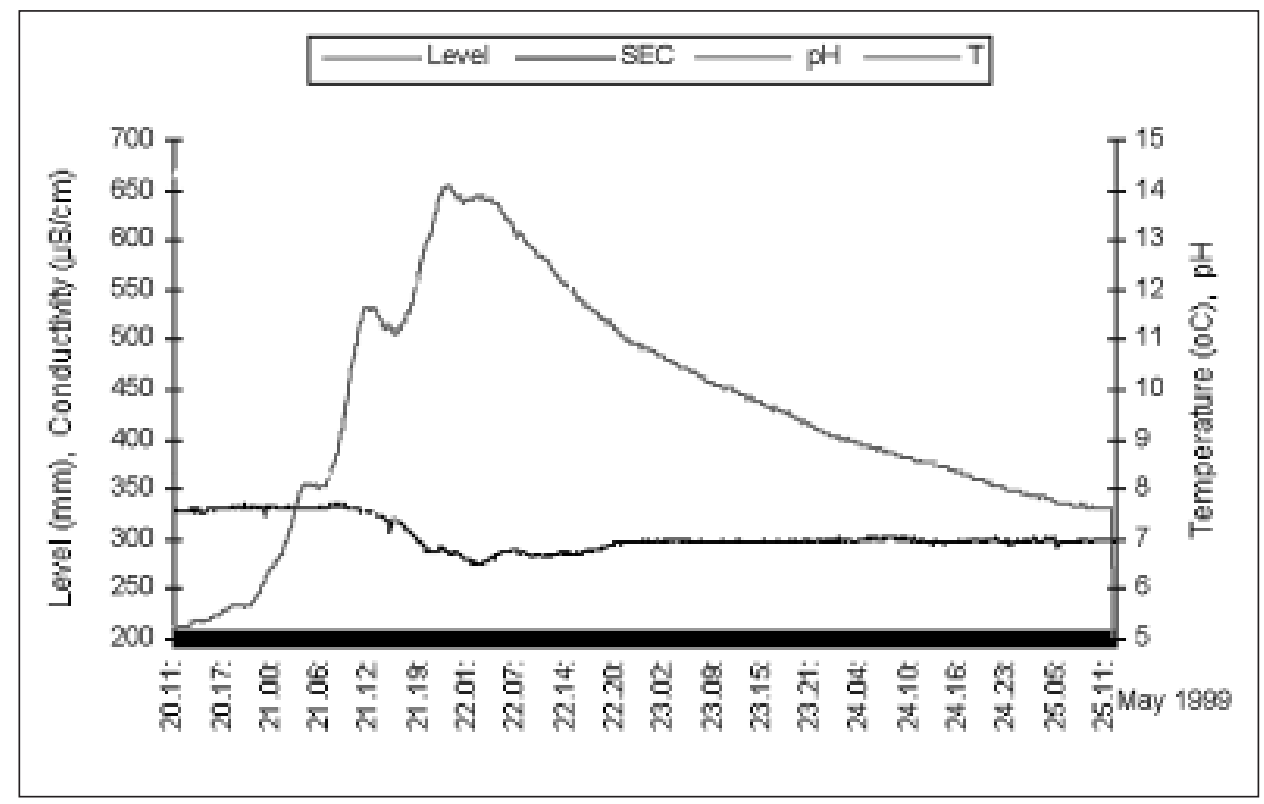

Fig. 6: Water quality measurement May 1999. 
ture and conductivity with an LF 597 profiLab instrument; $\mathrm{pH}$ with a Multiline $\mathrm{P} 4$ instrument and dissolved oxygen with Oxy 196.

At the time of the flood pulse from 20-25 May 1999, the first day measurements with these instruments and YSI 600 Sound showed identical values of temperature, conductivity and $\mathrm{pH}$, while DO measurements were problematic from the beginning, and, thus, we remained without results fit for use. On the following days, until the end of observations, we recorded smaller differences: for temperature up to $0.2^{\circ} \mathrm{C}$ and for conductivity up to $3 \mu \mathrm{S} / \mathrm{cm}$, except on 24 May 1999, when this difference was $8 \mu \mathrm{S} / \mathrm{cm}$, Figure 6 . At the same time, we took samples every hour for laboratory analyses to get the levels of carbonate, calcium, magnesium, chloride, nitrate, sulphate, o-phosphate, chemical oxygen demand (COD) and biochemical oxygen demand $\left(\mathrm{BOD}_{5}\right)$.

The negative peaks on graph of $\mathrm{pH}$ are interesting for further investigation. Those peaks are recognise once of year and present unknown heavily temporal pollution. Polluted samples should tested by toxicity tests.

\section{Toxicity tests}

The aim of selecting three microbiotests was to find out if there were any differences in their sensitivity. Namely, the conventional Daphnia toxicity test is legally adopted for testing the toxicity of samples from rivers during the regular annual biomonitoring of surface water quality.

We selected Daphnotoxkit $\mathrm{F}^{\mathrm{TM}}$ with the test organism Daphnia magna, Thamnotoxkit $\mathrm{F}^{\mathrm{TM}}$ with the test organism Thamnocephalus platyurus and Protoxkit $\mathrm{F}^{\mathrm{TM}}$ with the test organism Tetrahymena thermophila. Toxkits available on the market contain test organisms in inactive form and standard material needed to perform the tests. This assures very high reliability of the test results.

We found no positive, dose dependent responses samples where tested with the two crustaceans (Daphnia magna, Thamnocephalus platyurus). However, the protozoan Tetrahymena thermophila showed toxicity of straining water from a dump loaded with waste products from the chemical factory. EC20 was detected at a $40 \%$ sample.

On the basis of the results from the toxicity tests and the results from the chemical analyses, we see that the chemical analyses, solely, are not sufficient to detect the potential toxicity of samples. Besides that, the standardised Daphnia toxicity test was not sensitive enough to detect any toxicity of our samples. Our results are in a series of those which point out a need to use a battery of toxicity tests to improve the relevance of the test results, (Persoone et al, 2000, Drobne $\&$ Štrus, 2000). A combination of chemical measurements and biological data can provide an insight into water quality. A separate interpretation of these data, or lack of any of them, can be misleading.

\section{CONCLUSION AND RECOMMENDATIONS}

(a) The new, more sophisticated equipment with different probes (head, temperature, velocity, $\mathrm{pH}$, conductivity etc), is essential for the further development of hydrology.

(b) The new equipment gives us more accurate data, showing phenomena that were not properly recorded before, and which need additional research.

(c) The ultrasonic velocity meter with probes for water level and temperature measurements, and 
probes for water conductivity and $\mathrm{pH}$ are useful and could be used in monitoring of water regime.

(d) Tested equipment for measurement of suspended sediments and equipment for measurement of dissolved oxygen are not well enough well development for ordinary monitoring of water regime.

(e) The equipment and toxicity tests should be tested in field conditions, and needs some specific experience and training for proper handling in field conditions.

(f) All the raw data and the preliminary analysis will be collected and published on a CD for research and academic purposes.

\section{ACKNOWLEDGEMENT}

The Office of the Slovene National Commission for UNESCO supports presented research. The authors would also like to thank the Hydrometeorological Institute of Slovenia for providing the operational data.

\section{REFERENCES}

Brilly M., Rakovec J., Vrhovec T., Vidmar A., Gregorič G., Šraj M., 2000: Application of meteorological mesoscale model ALADIN-SI for hydrological forecast, Hydrology days, April 3-6, 2000, Jorge Ramirez, Colorado State University, Fort Collins, Colorado, 8-20.

Drobne, D., Štrus J., 2000: Toxicity determination of zinc and cadmium, single and in combination, with a battery of Toxkit microbiotests. In New Microbiotests for outline Toxicity Testing and Biomonitoring (G. Persoone, C. Janssen, W. De Coen) Kluwer Academic/ Plenium Publisher, 481-486.

Persoone, G., C. Janssen, W. De Coen, 2000: New microbiotests for routine toxicity testing and biomonitoring. Kluwer Academic/Plenium Publisher.

Rojšek, D., 1987: Fizično-geografske značilnosti in naravne znamenitosti porečja Notranjske Reke (Physico-geographical characteristics and natural features of the Notranjska Reka drainage basin), Varstvo narave, vol 13, 5-24, Ljubljana, Slovenia.

\section{EKSPERIMENTALNI MONITORING VODNEGA REŽIMA V REKI}

\section{Povzetek}

Reka Reka ima prispevno površino $422 \mathrm{~km}^{2}$. Ponika v Škocjanskih jamah, ki jih je UNESCO leta 1986 razglasil za svetovno dediščino. Sredi šestdesetih let so prenehali črpati vodo Reke za oskrbo Divače, ker se je njena kakovost poslabšala. V sedemdesetih letih je bila Reka ena od najbolj onesnaženih rek v Sloveniji. V začetku devetdesetih let je prišlo do zaprtja Tovarne organskih kislin, ki je bila največji onesnaževalec in kakovost Reke se je opazno izboljšala. 
V času visokih vod leta 1999 in 2000 smo izvedli meritve hitrosti, kalnosti, vrste fizikalnih in kemičnih parametrov ter teste strupenosti. Glavni cilj teh meritev je bilo preveriti mersko opremo $\mathrm{v}$ terenskih pogojih visokih voda, zbrati čim več podatkov ter primerjati uporabnost opreme.

Na osnovi dobljenih rezultatov lahko zaključimo:

(a) Nova oprema s sondami za zvezno merjenje različnih parametrov (nivo, temperatura, hitrost, $\mathrm{pH}$, specifična električna prevodnost...) ter shranjevanje izmerjenih vrednosti, je pomembna za nadaljnji razvoj hidrologije.

(b) Nova oprema daje točnejše rezultate, pokaže na pojave, ki prej niso bili primerno merjeni in ki jih bo potrebno dodatno raziskati.

(c) Ultrazvočni merilec hitrosti s sondami za meritve višine vode in temperature ter sonde za merjenje specifične električne prevodnosti in $\mathrm{pH}$ so zelo uporabne in bi jih lahko s pridom uporabljali pri monitoringu vodnega režima.

(d) Preverjanje opreme za meritve suspendiranih sedimentov ter opreme za merjenje vsebnosti raztopljenega kisika $v$ vodi je pokazalo, da še nista dovolj dobro razviti za redni monitoring vodnega režima.

(e) Opremo in toksične teste bi bilo potrebno preveriti v terenskih pogojih. Potrebne bi bile posebne izkušnje in izobraževanje za pravilno izvedbo $v$ terenskih pogojih.

(f) Vsi neobdelani podatki in predhodne analize bodo zbrani in objavljeni na CD-ju za raziskovalne in visokošolske namene.

\section{ZAHVALA}

Predstavljene raziskave je podprl Urad Slovenske nacionalne komisije za UNESCO. Avtorji se zahvaljujemo Agenciji za okolje za operativne podatke. 